\title{
White spot syndrome virus (WSSV) infectivity for Artemia at different developmental stages
}

\author{
Qin $\mathrm{Li}^{1{ }^{1 *}}{ }^{\text {, Jinghai Zhang }}{ }^{1}$, Yingjie Chen ${ }^{1}$, Feng Yang ${ }^{2}$ \\ ${ }^{1}$ Department of Biochemistry, Shenyang Pharmaceutical University, 103 Wenhua Road, Shenyang 110016, PR China \\ ${ }^{2}$ Key Laboratory of Marine Biogenetic Resources, Third Institute of Oceanography, SOA, 184 Daxue Road, Xiamen 361005, \\ PR China
}

\begin{abstract}
White spot syndrome virus (WSSV) is a major pathogen of cultivated shrimp, but its host range includes a large number of crustaceans. In this investigation, Artemia franciscana was tested for susceptibility to WSSV by the oral route. Both instars and adults were challenged, and the presence of WSSV was followed through to reproductive cysts and offspring using PCR. WSSV caused a much lower cumulative mortality in Artemia than in cultivated shrimp by $10 \mathrm{~d}$ post-challenge. Instars, adults and reproductive cysts were PCR positive. However, the virus was undetectable by PCR in nauplii that had hatched from PCR-positive reproductive cysts. The data indicate that WSSV or WSSV genomic DNA can be vertically transmitted from WSSV-PCR-positive instars to reproductive cysts, but this DNA is removed during hatching.
\end{abstract}

KEY WORDS: Susceptibility $\cdot$ Artemia $\cdot \mathrm{WSSV} \cdot$ Infection $\cdot$ PCR

\section{INTRODUCTION}

The global industry for cultivated penaeid shrimp has grown rapidly during the past 2 decades (Rosenberry 1999). White spot syndrome virus (WSSV) is a major pathogen of shrimp, and since 1993 it has caused high mortalities in the shrimp culture industry in the Asia-Pacific region (Inouye et al. 1994). WSSV has also been referred to as white spot syndrome associated baculovirus (Chang et al. 1996), or white spot bacilliform virus (Zhang et al. 2001), and its complete genomic DNA sequence was recently, in 1997, determined (van Hulten et al. 2001, Yang et al. 2001). Based on its morphology, genomic composition and on phylogenic analysis, WSSV has been assigned to the new genus Whispovirus within a new virus family, Nimaviridae (Vlak et al. 2002).

A most interesting feature of WSSV is its broad host range (Flegel 1997). It infects several species of penaeid shrimp cultivated in the Eastern/Western Hemispheres (Lu et al. 1997, Corsin et al. 2001), in addition to a wide range of other decapods and crustaceans, including crabs (Chen et al. 2000, Sahul Hameed et al. 2001) and fresh water crayfish (Huang et al. 2001, Jiravanichpaisal et al. 2001). Several studies have confirmed that many suspected decapod carriers of WSSV can transmit the virus to Penaeus monodon (Wongteerasupaya et al. 1996, Chang et al. 1998, Wang et al. 1998).

Artemia is widely used in hatcheries as live feed or as a feed additive for shrimp postlarvae. Chang et al. (2002) reported Artemia cysts that were PCR-positive for WSSV, indicating that Artemia might be susceptible to WSSV infection. In this investigation, Artemia instars and adults were challenged orally with WSSV, and PCR analysis was used to demonstrate that Artemia may occasionally be a passive carrier of WSSV. 


\section{MATERIALS AND METHODS}

Experimental Artemia. Commercial Artemia cysts (Sanders Company) that tested WSSV-negative by PCR (see below) were placed in a $1 \mathrm{l}$ aquarium tank at $30^{\circ} \mathrm{C}$ at a density of 600 cysts $\mathrm{l}^{-1}$ (in seawater at $5 \mathrm{ppt}$ ). Nauplii were harvested $12 \mathrm{~h}$ after the start of cyst hatching to ensure a $100 \%$ homogeneous instar I population. By feeding with live microalgae, some of the nauplii were acclimatized at a density of 300 nauplii $1^{-1}$ (in seawater at $5 \mathrm{ppt}$ ) prior to viral challenge, while others were transferred to another tank at a density of 300 nauplii $1^{-1}$ and cultured from hatching instars to the adult stage, at $30^{\circ} \mathrm{C}$ in 100 ppt seawater. Nauplii and adult Artemia were collected for infectivity and vertical transmission studies to determine their susceptibility to WSSV. Seawater was sand-filtered and boiled for $10 \mathrm{~min}$ before use in all experiments.

Preparation of viral extract for oral challenge tests. Pond-reared Penaeus japonicas shrimp naturally infected with WSSV were used as the source of viral inoculum for primary laboratory infections. A stock inoculum prepared from primary infected shrimp was injected into more laboratory shrimp to provide WSSVinfected tissue for oral challenge of Artemia. In detail, WSSV-infected $P$. japonicas shrimp with prominent white spots were collected from culture ponds in Tong' an, Xiamen, east China, in October 1996. The infected cephalothroacic tissues (gill, stomach, midgut, etc.) were homogenized in TN buffer $(20 \mathrm{mM}$ Tris- $\mathrm{HCl}$ and $400 \mathrm{mM} \mathrm{NaCl}, \mathrm{pH} 7.4$ ) at $0.1 \mathrm{~g} \mathrm{ml}^{-1}$. After centrifugation at $2000 \times g$ for $10 \mathrm{~min}$, the supernatant was filtered $(0.22 \mu \mathrm{m})$ and injected $(1: 100$ dilution in $0.9 \% \mathrm{NaCl})$ intramuscularly into the lateral area of the 4 th abdominal segment of healthy shrimp. Four days later, WSSV infection was verified by PCR, and abdominal muscle was collected, mixed with powdered algae in the proportion 1:5 (w:w), and $10 \mathrm{~g}$ of this material was homogenized in $100 \mathrm{ml}$ PBS solution. This preparation was called viral feeding mixture (VFM) and stored at $4^{\circ} \mathrm{C}$ until used.

Infectivity and vertical transmission studies. For WSSV infectivity studies, 5 replicate groups (150 ind. each) of nauplii and adult Artemia were fed VFM as described below. Before oral challenge, seawater was exchanged completely and the Artemia were starved for $12 \mathrm{~h}$. Nauplii and adults were then fed twice a day with VFM at the rate of $1: 1000 \mathrm{ml}(\mathrm{v}: \mathrm{v})$. During the challenge, aeration was sufficient to give good oxygenation and keep the VFM in suspension. Seawater was replaced totally every $24 \mathrm{~h}$ by filtration through micromesh gauze, on which the Artemia were gently but thoroughly rinsed with $3 \times 100 \mathrm{ml}$ sterilized seawater. The Artemia were then transferred to a new tank and freshly prepared VFM was added for the next
$24 \mathrm{~h}$ challenge cycle. On Days 3 to 9, seawater was exchanged and the Artemia were fed with live microalgae instead of VFM to remove residual virus. Survival was determined on Day 10. After the last feeding, the challenged Artemia were starved for $12 \mathrm{~h}$ before PCR analysis. Twenty prawns were also fed with VFM every $12 \mathrm{~h}$ for $2 \mathrm{~d}$, and then cultured for an additional $8 \mathrm{~d}$ with feed changed to WSSV-PCR-negative shrimp meat. Survival was determined daily until Day 10.

For vertical transmission experiments, some of the challenged instars were transferred to a new tank and cultured to sexual maturity to hatch cysts (oviparous reproduction) at $30^{\circ} \mathrm{C}$ in $100 \mathrm{ppt}$ seawater by feeding with live microalgae. The reproductive cysts were collected and the offspring nauplii were hatched at $30^{\circ} \mathrm{C}$ in $5 \mathrm{ppt}$ seawater. Adults, reproductive cysts, and offspring nauplii from the cysts were collected for PCR analysis.

$\boldsymbol{P C R}$ analysis. WSSV-DNA was detected using a commercial 1-step PCR detection kit (WSBV PCR Detecting Kit). Template DNA was prepared from Artemia according to the kit instructions. Briefly, $20 \mathrm{mg}$ Artemia (i.e. instars, adults, reproductive cysts or hatched nauplii) was added to an Eppendorff tube containing $100 \mu \mathrm{l}$ lysis buffer and homogenized using a sterilized toothpick. After centrifugation at $2000 \times g$ for $2 \mathrm{~min}, 5 \mu \mathrm{l}$ silica was added to the supernatant followed by gentle agitation at $4^{\circ} \mathrm{C}$ for $10 \mathrm{~min}$. The mixture was centrifuged at $2000 \times g$ for $15 \mathrm{~s}$, the supernatant was discarded and the pellet was washed with $200 \mu \mathrm{l} 70 \%$ ethanol and suspended in $10 \mu \mathrm{l}$ distilled deionized water followed by incubation at $55^{\circ} \mathrm{C}$ for $5 \mathrm{~min}$. After centrifugation at $4000 \times g$ for $5 \mathrm{~min}$, the supernatant was used as a template for PCR using the following cycling conditions: $94^{\circ} \mathrm{C}$ for $2 \mathrm{~min}$ followed by 35 cycles of $94^{\circ} \mathrm{C}$ for $1 \mathrm{~min}, 55^{\circ} \mathrm{C}$ for $1 \mathrm{~min}, 72^{\circ} \mathrm{C}$ for $1 \mathrm{~min}$ and a final extension at $72^{\circ} \mathrm{C}$ for $10 \mathrm{~min}$. The specific WSSV PCR amplicon (360 bp) was detected by electrophoresis in $1.2 \%$ agrose gels, ethidium bromide staining and UV transillumination.

Table 1. Artemia. Cumulative mortality (\%) in nauplii and adult stages (5 replicates) challenged or not challenged with WSSV at Day 10 post-challenge

\begin{tabular}{|c|c|c|c|c|}
\hline \multirow{2}{*}{$\begin{array}{l}\text { Replicate } \\
1\end{array}$} & \multicolumn{2}{|c|}{$\begin{array}{c}\text { Nauplii } \\
\text { Challenged Control }\end{array}$} & \multicolumn{2}{|c|}{$\begin{array}{c}\text { Adult } \\
\text { Challenged Control }\end{array}$} \\
\hline & 25.3 & 18.7 & 10.0 & 5.3 \\
\hline 2 & 26.7 & 16.7 & 19.3 & 8.0 \\
\hline 3 & 33.3 & 20.0 & 18.7 & 6.7 \\
\hline 4 & 25.8 & 15.3 & 13.3 & 6 \\
\hline 5 & 32.0 & 20.7 & 18.0 & 8.7 \\
\hline Mean & 28.6 & 18.3 & 15.9 & 6.9 \\
\hline$t$-test & \multicolumn{2}{|c|}{9.53} & \multicolumn{2}{|c|}{6.717} \\
\hline $\mathrm{p}$ & \multicolumn{2}{|c|}{$\mathrm{p}<0.01$} & \multicolumn{2}{|c|}{$\mathrm{p}<0.01$} \\
\hline
\end{tabular}




\section{RESULTS AND DISCUSSION}

Cumulative mortality in WSSV-challenged Artemia on Day 10 post-challenge was significantly lower than that in marine shrimp (Fig. 1). Even though cumulative mortalities in Artemia were relatively low (29\% for nauplii and $16 \%$ for adults), a $t$-test comparing the nauplii and adult stages showed that differences in mortality between the challenged and unchallenged Artemia were significant at $\mathrm{p}<0.01$ (Table 1). VFM was fed to a fresh batch of prawns, all of which died with prominent white spots by $10 \mathrm{~d}$ post-challenge (Fig. 1). In contrast to the infected prawns, WSSVinfected Artemia showed no obvious gross signs of infection such as lethargy and lack of appetite, and exhibited normal swimming and feeding behavior. Relatively low cumulative mortality without obvious signs of disease suggested that Artemia had the potential to serve as a long-lived carrier of WSSV. However, this needs to be verified in further tests in which WSSV-challenged Artemia are cultured for longer periods and are then used in prawn-challenge experiments.

WSSV-challenged nauplii and adult Artemia yielded a clear WSSV-specific PCR amplicon (360 bp) (Fig. 2, Lanes 2 and 3), and no PCR product was amplified in the unchallenged control groups (Fig. 2, Lane 7). The prawns fed with the VFM also gave strong WSSV-

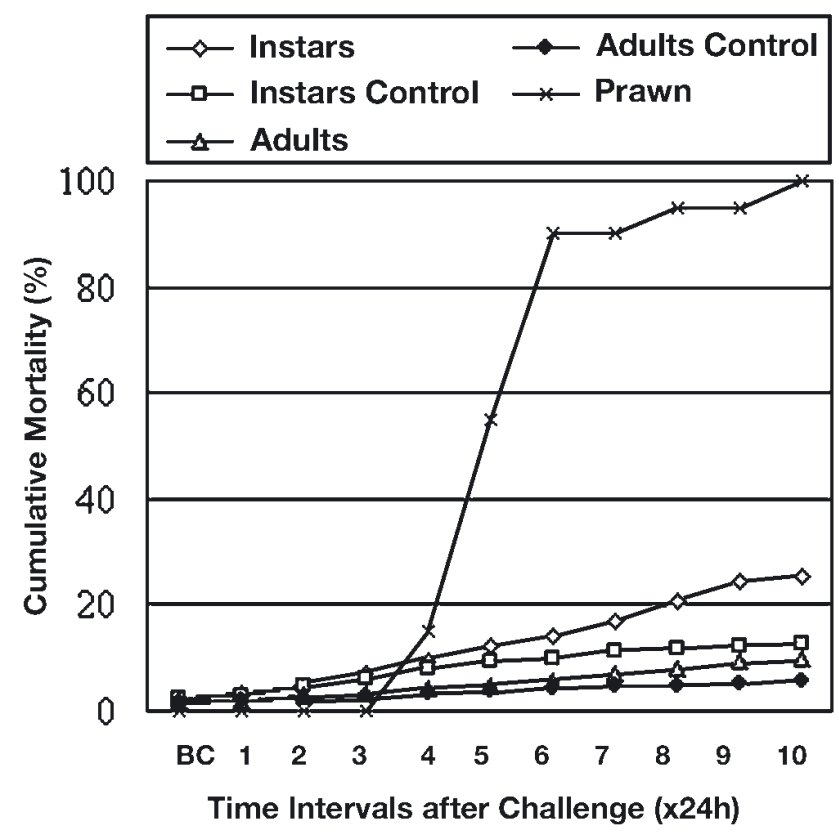

Fig. 1. Artemia franciscana. Cumulative mortality after oral WSSV-challenge. Artemia were divided into replicate challenge and control groups, each containing 150 individuals for each developmental stage (instars and adults). The positive control group comprised 20 prawns. BC: before challenge

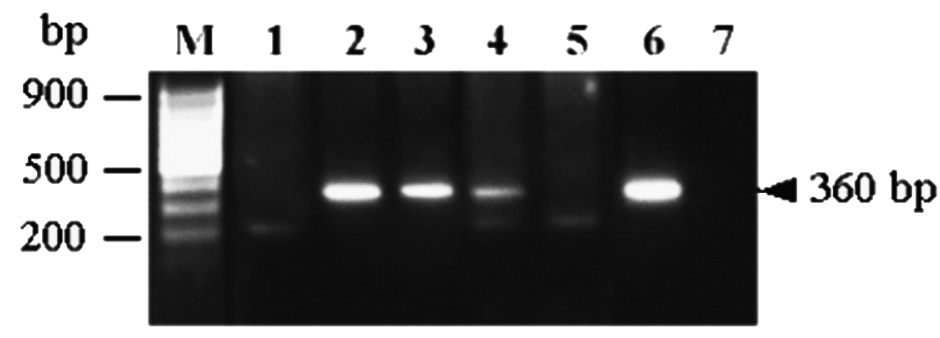

Fig. 2. PCR detection of WSSV-DNA in control and WSSVchallenged Artemia franciscana. M: 100 bp ladder; Lane 1: canned Artemia cysts; Lane 2: challenged nauplii; Lane 3: challenged adults; Lane 4: reproductive cysts produced from challenged adults; Lane 5: nauplii hatched from the reproductive cysts; Lane 6: prawn fed with viral feeding mixture (VFM) as positive control; Lane 7: unchallenged Artemia adults as negative control

PCR-positive reactions (Fig. 2, Lane 6). In the vertical transmission test, similar WSSV-positive PCR results were observed in the adults and reproductive cysts arising from challenged instars (Fig. 2, Lanes 3 and 4). However, nauplii hatched from these cysts were PCR negative (Fig. 2, Lane 5). No PCR amplicon was detected for the canned cysts used as the source of Artemia for all experiments (Fig. 2, Lane 1).

The results we obtained from infectivity and vertical transmission studies suggest that Artemia may be susceptible to WSSV and may transmit the virus from hatching instars to adults and from adults to reproductive cysts. However, the finding that nauplii hatched from these cysts were WSSV-PCR negative indicates that WSSV is removed during hatching and rinsing of the nauplii. Indeed, it has been shown previously that nauplii hatched from PCR-positive cysts are non-infectious (Chang et al. 2002), suggesting that the positive PCR reaction is likely to be due to the presence of noninfectious WSSV DNA (Lan et al. 2002). However, the possibility that infectious WSSV may sometimes be present internally in reproductive cysts derived from infected Artemia suggests that prawn-hatchery operators should use discretion when postlarvae are fed Artemia biomass (larvae and adults) produced in salt works near shrimp farms.

Acknowledgements. This work was supported by the Third Institute of Oceanography and Fund of Chinese '863' Program. We would like to thank Dr. P. Xia (University of Arizona) and Professor $\mathrm{X}$. Xu (The Third Institute of Oceanography, China) for helpful suggestions.

\section{LITERATURE CITED}

Chang PS, Chen HC, Wang YC (1998) Detection of white spot syndrome associated baculovirus in experimentally infected wild shrimp, crab and lobsters by in situ hybridization. Aquaculture 164:233-242 
Chang YS, Lo CF, Wang YC, Kou GH (1996) Identification of white spot syndrome associated baculovirus (WSBV) target organs in the shrimp, Penaeus monodon by in situ hybridization. Dis Aquat Org 27:131-139

Chang YS, Lo CF, Peng SE, Liu KF, Wang CH, Kou GH (2002) White spot syndrome virus (WSSV) PCR-positive Artemia cysts yield PCR-negative nauplii that fail to transmit WSSV when fed to shrimp postlarvae. Dis Aquat Org 49: $1-10$

Chen LL, Lo CF, Chiu YL, Chang CF, Kou GH (2000) Natural and experimental infection of white spot syndrome virus (WSSV) in benthic larvae of mud crab Scylla serrata. Dis Aquat Org 40(2):157-161

Corsin F, Turnbull JF, Hao NV, Mohan CV, Phi TT, Phuoc LH, Tinh NT, Morgan KL (2001) Risk factors associated with white spot syndrome virus infection in a Vietnamese riceshrimp farming system. Dis Aquat Org 47(1):1-12

Flegel TW (1997) Special topic review: major viral diseases of the black tiger prawn (Penaeus monodon) in Thailand. World J Microbiol Biotechnol 13:433-442

Huang $\mathrm{CH}$, Zhang LR, Zhang JH, Xiao LC, Wu QJ, Chen DH, Li JKK (2001) Purification and characterization of white spot syndrome virus (WSSV) produced in an alternate host: crayfish, Cambarus clarkii. Virus Res 76:115-125

Inouye K, Miwa S, Oseko N, Nakano H, Kimura T (1994) Mass mortalities of cultured kuruma shrimp, Penaeus japonicus in Japan in 1993: electron micrscopic evidence of the causative virus. Fish Pathol 29:149-158

Jiravanichpaisal P, Bangyeekhun E, Soderhall K, Soderhall I (2001) Experimental infection of white spot syndrome virus in freshwater crayfish Pacifastacus leniusculus. Dis Aquat Org 47:151-157

Lan YS, Lu W, Xu X (2002) Genomic instability of prawn white spot bacilliform virus (WSBV) and its association to virus virulence. Virus Res 90(1-2):269-74

Editorial responsibility: Timothy Flegel, Bangkok, Thailand
Lu Y, Tapay LM, Gose RB, Brock JA, Loh PC (1997) Infectivity of Yellow-head virus (YHV) and the Chinese baculolike virus (CBV) in two species of penaeid shrimp, Penaeus stylirostris (Stimpson) and P. vannamei (Boone). In: Flegel TW, MacRae I (eds) Diseases in Asian aquaculture III. Asian Fisheries Society, Manila

Rosenberry B (1999) Farmed shrimp up by 12 per cent. Fish Farmer Jan/Feb 1999:40-41

Sahul Hameed AS, Yoganandhan K, Sathish S, Rasheed M, Murugan V, Jayaraman K (2001) White spot syndrome virus (WSSV) in two species of freshwater crabs (Paratelphusa hydrodomous and P. pulvinata). Aquaculture 201: 179-186

van Hulten MC, Witteveldt J, Peters S, Kloosterboer N and 5 others (2001) The white spot syndrome virus DNA genome sequence. Virology 286:7-22

Vlak JM, Bonami JR, Flegel TW, Guang HK, Lightner DV, Lo CF, Loh PC, Walker PJ (2002) Nimaviridae. A new virus family infecting aquatic invertebrates. Report from the XIIth Int Congr Virol, Paris. Oral and poster presentation

Wang YC, Lo CF, Chang PS, Kou GH (1998) Experimental infection of white spot baculovirus in some cultured and wild decapods in Taiwan. Aquaculture 164:221-231

Wongteerasupaya C, Wongwisansri S, Boonsaeng V, Panyim S, Pratanpipat P, Nash GL, Withyachumnarnkul B, Flegel TW (1996) DNA fragment of Penaeus monodon baculovirus PmNOBII gives positive in situ hybridization with White-spot viral infections in six penaeid shrimp species. Aquaculture 143:23-32

Yang F, He J, Lin X, Li Q, Pan D, Zhang X, Xu X (2001) The complete genome sequence of the shrimp white spot bacilliform virus. J Virol 75:11811-11820

Zhang XB, Xu LM, Xu X (2001) Detection of prawn white spot bacilliform virus by immunoassay with recombinant antigen. J Virol Methods 92(2):193-197

Submitted: December 5, 2002; Accepted: August 19, 2003 Proofs received from author(s): November 13, 2003 